\title{
ENCOURAGING ETHICAL BEHAVIOUR IN PUBLIC ADMINISTRATION BY HUMAN RESOURCE MANAGEMENT
}

\author{
Zuzana Dvořáková \\ Department of Human Resource Management, Faculty of Business Administration, University of Economics, \\ W. Churchill 4 Sq, 13067 Prague 3, Czech Republic \\ Telephone: + 420 224095308; Fax: + 420 224095328; E-mail: zdvorak@vse.cz
}

Received 0609 2005; accepted 23092005

\begin{abstract}
The public administration reform in the Czech Republic set off with a reform of the territorial public administration at the end of the 90s. The reform established a joint public administration model in the territories, power decentralization, and de-concentration of operative functions from ministries to regions and municipalities. The reform outcomes largely depend on the quality of human resources in public administration, their ethical values, and status in the society. The public sector always needs to solve a traditional ethics dilemma whether public officials serve citizen or politician purposes. The paper is aimed at ethical values in the Czech public administration, ethics dilemmas in the public sector, and human resource management in territorial self-governments supporting ethical behaviour. An abnormal situation comes into being in the Czech Republic as public officials incline to serving neither citizens nor politicians. Some municipal authorities strive to improve public administration ethics by designing and implementing new HR practices, codes of ethics and anticorruption programmes.
\end{abstract}

Keywords: ethics, values, human resource management, public administration, corruption, Czech Republic.

\section{Introduction}

The public administration reform in the Czech Republic set off with a reform of the territorial public administration at the end of the 90 s. Its objectives included modernizing the central state administration, improving the quality of the functioning of the public administration as a whole, and approaching citizens. The reform established a joint model of public administration in the territories, i.e. local selfgovernment executes its own competencies and at the same time the delegated powers, decentralization and de-concentration of powers and operative functions from the civil service on regional and municipal levels.

Initiatives stressing economy, effectiveness and efficiency of public administration urge more or less fears whether such trends of public reforms don't damage ethics and cause other values traditionally connected to public services to disappear (Pomahač, Vodikova 2002: 200). This is influenced by corruption behaviour of political elite and public servants publicized in the media and alarming statistics of the number of criminal cases versus public matters and corruption behaviour (Frederickson and Walling 1999). For example, in 2004 the Police of the Czech Republic filed 287 criminal cases related to corrupt practices and 248 ones of public servant's power malpractice and obstruction of public servant's task due to misprision. The total number of criminal activities related to corruption reached the highest level in the last 10 years and is comparable with the situation in 1995 (Corruption Report in the Czech Republic in 2004 and Performance Report about Updated Governmental Anticorruption Programme 2005). A remarkable growth was revealed in corruption practices, i.e. bribe acceptance, bribing and indirect corruption, on the contrary, a visible decrease was shown in public servant's power malpractice and obstruction of public servant's task due to misprision (ibid.).

The paper aims to illustrate interdependency between human resource management (HRM) and ethical values, analyse ethics issues in public servants' behaviour, highlight ethics dilemmas in the Czech public administration and identify human resource (HR) practices that prevent corruption behaviour and 
support ethical values in public administration. The content covers HR policies and practices applied in Czech territorial self-governments, a case dealing with the Anticorruption Programme of the City of Prague, and finally recommendations on implementing ethical competencies into human resource management.

The methodology of this essay employs approved scientific methods. The basis lies in retrieving, classifying and analysing secondary sources about public administration ethics and ethical behaviour of officials. Mapping of the general state serves the purpose of comparison and assessment of general and unique appearances in the field of ethical acting in the Czech environment. The testimony to specific features is given by analyses of published articles on corruption in the Czech Republic, findings of the research on HRM work in territorial self-government bodies, and the example of Anticorruption Programme. Critical assessment of the documented facts facilitates both defining premises for the improvement of the existing practice and generalizing advices on changes in HRM in public administration.

\section{Human Resource Management and Public Administration}

HRM as a concept of personnel work represents a set of principles that are designed to lead to an integrated organization, commitment and loyalty of employees, flexibility and quality of work (Guest 1987: 503). All HRM models created in the 80 s of the $20^{\text {th }}$ century are common in emphasizing the dominance of external influences, the need to implement strategies, the compliance with the single direction from strategy to people management procedures and the limited ability of managers to influence strategic choices (Sparrow and Hiltrop 1994: 5-24). It is characteristic for HRM that (Dvouikevi et al. 2004: 48):

- It is strategy and business oriented, i.e. HR strategy is integrated into company strategies and people management is a managerial oriented activity,

- High importance is attached to strong corporate culture that arises from the vision of executive directors and their leadership style,

- Responsibility for people management lies on line managers and the HR department provides support services and consultation,

- Within industrial relations the direct bind between the employer and employee empowers and the intermediate role of trade unions weakens,

- Stress is placed on performance orientation, assurance of quality for customers and achievement of customer satisfaction,

- Strong emphasis is attached to loyalty and commitment (activity) of employees towards the organization.

Even though that in the last few years we encounter extensive doubts about the employability of HRM in enterprise practise, especially in the cases of strategic integration, consistency of HR politics and achievement of employee loyalty to the employer, it still stimulates changes in approaches towards employees as for it captured the interest of managers with its rhetoric about corresponding concerns of managers and employees and the assurance of the needs of all involved parties (Branine and Dvořáková 2000: 84-85). Two of the models' premises are rather interesting for HRM in public administration: if organizational loyalty is joint with commitment to work than it leads to high job satisfaction and high job performance, and if recruitment and staff stabilization processes assure top-quality employees than high quality standards and outstanding goodwill become reachable. For public administration we can therefore conclude that staffing, training and development of human resources based on traditional public administration values become a precondition of high quality of public services.

\section{Ethics and Values in Public Administration}

Ethics contribute to the quality of life and one of their parts - normative ethics that study general rules, principles and codes of moral behaviour (Maukkovi et al.1996: 273) - turns to become a subject matter for initiatives focusing on the improvement of quality of work life. Ethics can be defined as a value trying to specify right vs. wrong and good vs. evil, however having a narrower content than value. This results from the perception of value to which we can find up to 180 different definitions (Maříková et al. 1996: 375), from which it is hereby adequate to name e.g. the approach of M.Rokeach. According to his definition, if a person shares a certain value it means that he/she holds an opinion that a particular way of acting or a target state of existence deserves due to personal and social reasons preference over alternative ways and target states, respectively (ibid.). In public administration we find sets of traditional values covering both ethic values (integrity, fairness) and other values, as democratic (role of law) and professional values (effectiveness, service), based on the society, democracy and professionalism (Vermeulen 1998). 
The importance of particular values changes over time. It is evident at the beginning of the implementation of a territorial public administration reform when regional and municipal self-governments emphasise quality, change, innovation and other managerial lingo and when traditional democratic or ethic values lay on the edge of local politicians' interests or change their original meaning, e.g. responsibility for processes instead for results.

Performing administrative activities makes it obvious that there is a close relation between ethics and other values long-established and expected in public administration. From these it is mainly the sense of responsibility, e.g. municipal servant's behaviour can be classified as unethical and unaccountable when he/ she produces an industry building resolution for a residential area.

The problem consists in conflicts of various values and traditional ethics dilemma: whom do public servants serve - supervisors, citizens or politicians? Public servants are ruled by laws, public sector regulations and others instructions, but they can perceive conflicts with their own sense of rights and wrongs. Their fairness, non-political neutrality should be kept unquestionable (Vigoda 2000). However, what limits subsist for information secrecy if it is in antagonism with principles of truth and credit? Is it possible to criticise official governmental programmes in the media? Fundamental changes of Czech political and economic systems in 1989 together with long-term processes of the civic society development generate an environment in which Czech public servants have solved the ethics dilemma established in any public services in a way of not wanting to serve citizens nor politicians and rather would like to satisfy their own needs.

\section{1. Professional Ethics and Ethical Dilemmas in the Czech Public Administration}

Professional ethics of public officials are being perceived as a moral code and therefore pose firmer requirements on civil servants than on average members of the society. The causality results from the danger that he/she may abuse the power or authority joint with his/her job position.

Corruption reasons in the Czech Republic arise from political elite attitudes towards corruption, public responsibility and morale, from the insufficient economic security of public servants and the lack of professional ethics in public services. The most important problems in public administration occur:
- In immediate contacts between private and public sectors, where the most frequent corruption cases are registered,

- In areas, where politics meet public administration. The development of their relationship can be solved by accepting a behaviour code of public servants and/or encouraged by motivating public employees to responsible behaviour.

An illustrative case of a political elite attitude towards corruption and in general to public responsibility and morale is in the Stanislav Gross' story (http:// cs.wikipedia.org/wiki/Stanislav Gross). ${ }^{1}$ Gross' public behaviour and inability to accept any responsibility significantly weakened the Social Democrats' positions in the society to a level that was reflected in opinion polls done in April 2005 when they dropped far behind the communist party.

\section{2. HRM and Professional Ethics in Territorial Self-governments}

HRM covers hard and soft issues, including ethical reasoning. The latter one is "a process of recognizing, examining and articulating values, beliefs, principles and contexts that impact decision making and action(s), fostering responsibility, respect, awareness, integrity, reflection, fairness and honesty" (Ethical Reasoning Mini-Guide 2005). Ethical behaviour patterns in public administration support providing of public services in accordance with the social justice and the civic society principles.

The ethical behaviour of public officials can be saved and developed by:

- Educational systems preceding the accession into the public sector, especially in case of civil servant appointments,

- Training and development,

- The acceptance of written regulations and the code of ethics of public administration employees,

- Influence of supervisors and their leadership style.

What does HRM represent in Czech territorial selfgovernments, in particular in the context of ethical issues? Managing public officials primarily rest on personnel administration and organization of training, thus ethical issues remain on the edge of public administration management and leadership. Such findings were revealed by a representative survey covering 809 respondents who deal with HRM at regional, municipal and local authorities (Koudelka, Bakešová and Štainer 2005). As well it is evident that: 
- Larger authorities establish personnel departments that often perform personnel activities in unproductive and inefficient ways.

- In most of the authorities there is no elaborate recruitment and selection system. Employee selection is negatively influenced by the lack of professionals, the larger number of applicants in regions with higher unemployment, the shortage of financial resources for recruitment and employment, the difficultness to set down selection criteria and sometimes by favoured pushes.

- $\quad$ All authorities pay certain attention to public employee training which is directed by the Act No. 312/2002 Col., on Territorial Self-government. Training concepts exist in almost $80 \%$ of authorities and heads of authorities take care of training processes. The training needs are primarily identified by the Act, then by supervisors and also based on public employee requirements.

- Performance appraisal concepts are found in approximately one half of authorities. Approaches to performance appraisal seem to be very general, e.g. a free description of performance, an occasionally made up degree scale for quality assessment, employee comparison etc. In most cases, performance appraisal is accepted rather as a need and largely as a merit pay basis. It becomes a starting point for training and development in only $1 / 3$ of authorities and it influences career development and promotion in $1 / 3$ of authorities, as well.

- Successor plans are compiled in about $40 \%$ of authorities and personal development plans are exceptional cases.

- $\quad$ Surveyed public employees agree that they are well informed about professional matters and offices' issues.

- A code of ethics is elaborated and probably applied in roughly $1 / 3$ of authorities that cover higher territorial authorities, as regional offices and municipalities. The situation in this area is not so affirmative in municipal (town) and local authorities. The outcome is that the importance of a code of ethics is greatly appreciated by selfgovernments of higher rank.

In summary, territorial self-governments will have to elaborate, implement and integrate human resource policies and practices that are known as "best practices".

The integral components of such changes are transparent processes, strict employee selection, training and development, and promotion (Kleibl,
Dvořáková and Šubrt 2001: 5-17). All mentioned HR practices should involve ethical values and traditional public sector values as part of core competencies. This meets all other outcomes of the survey: HR managers and specialists are especially keen on designing and implementing appropriate guidelines for public administration on job description and job analysis, performance appraisal, training and development, and compensation.

\section{Corruption and Anticorruption in Public Administration}

The focus of corruption behaviour of civil service and territorial self-governments embodies in performing administrative activities and contracting state and public orders - selection procedures (Corruption Report in the Czech Republic in 2004 and Performance Report about Updated Governmental Anticorruption Programme 2005: 11). Corruption has either monetary or non-monetary forms; the latter ones are difficult to substantiate. To prove by evidence organized and branched corruption in public administration is rather complicated due to its grooviness and cover-up methods of communication between the bribing and bribed persons (ibid). It results from secrecy and the fact that corruption changes its formats in context of political, economic and social conditions. When illegal or unethical applications of governmental or administrative powers arise in favour of personal or political benefits; this means that public concerns are subordinated to private purposes, it takes on a shape of misusing power and happens by counteracting rules of law and ethical behaviour standards, especially counteracting obligations and accountabilities (Pomahač and Vodákova 2002: 149).

The anticorruption arrangements in the Czech Republic are prepared and coordinated on the governmental level by an interdepartmental coordinative commission against corruption established by the Ministry of Interior in 2003. The extent and the quality of governmental anticorruption measures meet a lack of financial means that makes it almost impossible to implement all desired provisions. For example, the Group of States against Corruption of the Council of Europe (GRECO) points out a low level of engagement of the Czech Republic in balanced corruption research and deficiencies in internal anticorruption policy, like any absence of corporation accountability for corruption criminal acts, the immunity system for Members of Parliament in the case of immunity decrement because there are no applicable tangible and balanced criteria, the prec- 
lusive prosecution system after terminating MP's appointments, a weak role of the public ombudsman etc.

The Ministry of Interior orientates its activities to nonlegislative arrangements, like methodologies, research, education, training, information campaigns, elaborating analytical studies, organizing conferences, designing anticorruption websites, supporting nongovernmental organizations, e.g. the Transparency International etc.

The corruption in the public sector enjoys a friendly environment due to two at risk areas for blooming of criminal acts: when public administration and private enterprises come together and that public service represents a relatively large sector of the economy. In Czech circumstances such an environment denotes:

- A complexity of public administration functioning,

- $\quad$ Legislative sources of corruption behaviour, i.e. law vagueness and ambiguity, legislative regulations and administrative rules, overcentralisation of powers in one's hands without any possibility of independent external control, ineffective feedback controls, slow-paced and complicated problem-solving processes, a sanction absence for passing powers, an absence of control mechanisms,

- A functionless financial control performed by an independent office,

- $\quad$ Performing some high-level public positions by politically established persons,

- Connecting the public and private sectors, e.g. participation of public officials in boards of directors.

For illustration: the Ministry of Finance considers that the crucial anticorruption barriers mainly base upon ambiguity and inaccuracy of law wordings that allow various interpretations (Corruption Report in the Czech Republic in 2004 and Performance Report about Updated Governmental Anticorruption Programme 2005: 20). Coming from this statement the Ministry suggests aiming the anticorruption measures to improvement in the following ways:

- Collaboration between public organizations with no judgment constraints,

- Clearing worthless administrative ballasts,

- A truly effective act on conflicts of interest,

- Stabilization when the Act on Civil Service becomes effective completely, incl. planning of sufficient financial sources and designing social status of educated and professionally trained civil servants. The Act should have come into force by 1.1.2004 but it was amended several times.
Its last amendment postponed the enforcement to 2007 (Act No. 626/2004 Coll.), which is the main reason why the preparation for civil service couldn't proceed according to the Act. The corruption themes and anticorruption measures are compulsory topics in civil service orientation and training programmes.

The corruption abatement in the Czech Republic makes use of institutional and legal instruments, i.e. the parliamentary control of public administration, the judicial control of public administration and selfadministrative control. The updated governmental programme against corruption lays on central state legislative and organizational provisions and international assistance (Corruption Report in the Czech Republic in 2004 and Performance Report about Updated Governmental Anticorruption Programme 2005). It includes, at least in organizational areas: identifying and analysing sources and forms of corruption behaviour, elaborating and updating internal anticorruption programmes, among other. Civil service and territorial authorities have to respect the Government decree No. 270, becoming effective $21^{\text {st }}$ March 2002, to the Code of Ethics of Public Employees and make an effort to increase both professional and ethical levels of employees. Inspired by this, some institutions create their codes of ethics that become part of training programmes encouraging personal integrity, developing professional honour, supporting motivation and belonging, e.g. the Code of Ethics of the Ministry of Labour and Social Affairs, the Code of Ethics of the Government Office of the Czech Republic (www.korupce.cz). Public employees are obligatory familiarized with internal anticorruption programmes and codes of ethics during introductory or further training programmes.

\section{Case: Anticorruption Programme of the City of Prague}

The Municipality of the City of Prague often becomes a media subject to discuss of how high-level public officials strive achieving an anticorruption environment. Its Anticorruption Programme is thoroughly elaborated and implemented as part of long-term transformation processes into a modern territorial selfgovernment that performs in productive and effective ways, is professional, open, transparent, controlled and revisable.

The Programme establishes provisions against corruption on prevention, investigation and solutions of existing corruption. It puts emphasis on preventive measures, comprehensive anticorruption legislation 
and internal regulations, identifying predisposed activities, analysing legal and administrative arrangements, partnership with the civic society and planning to make corruption a highly unsafe activity with low fruitfulness (Šimčíková 2005).

The Anticorruption Programme of the City of Prague aims at themes and measures in three areas: the organization, human resource management and collaboration with other organizations and the public. The next short descriptions of each area provide illustrative overviews of applied anticorruption practices.

The organization includes the following:

- A uniform organizational Municipality structure,

- Editing key internal regulations, e.g. Work Rules, Rules of the Organization, the Nomenclature, Clerical Rules of the City of Prague, the Bylaw of the Municipality Director to the Deadline Abidance,

- Identifying and analysing activities that are at risk for corruption acts, i.e. areas like decision making, licensing and permitting,

- $\quad$ Applying work methods that eliminate corruption incidences, e.g. Guidelines for the Debt Administration of the City of Prague in dealing with the Third Juridical Person, Guidelines for Contracting Public Orders, Guidelines for the Grant Finality Abidance etc.

- Using a consequent control system, in particular reinforcing a financial control,

- Establishing of the Anticorruption Commission whose members are the Municipality Director, representatives of the Police of the Czech Republic, the Prosecution and the Association of Civil Consultant Organizations,

- Disseminating information between Municipality units,

- $\quad$ Founding an address and a telephone number for sending inducements and suggestions.

Human resource management pays enhanced attention to strict employee selection underlining morale characteristics of high-level officials, regular professional training and social skills development aimed at achieving organization's ethical behaviour. Tangible measures consist of:

- Editing the Code of Ethics of the City of Prague,

- The Bylaw on Prohibition of Other Income Activities,

- $\quad$ Setting up selection procedures applied to public employee vacancies and setting precise criteria for deployment based on job description and job analysis,
Strict employee selection focused on timely identification of applicants who would probably fail due to their personal characteristics in certain situations, e.g. persons with extreme frustration immunity, high self-confidence, having a tendency to depreciate a risk, individuals preferring material values and orientated to external wealthy life style and social prestige,

Orientation courses for new employees and regular professional training, incl. seminars regarding corruption and anticorruption, and social skills development with an emphasis on openness and interactivity when negotiating with subcontractors and/or presenting in public places.

The collaboration with other organizations and the public includes cooperation and joint actions with public authorities, non-governmental organizations engaged in struggling against corruption, the public and the media, like establishing and operating the Public Relations Department, disseminating information and enlarging Information Centre services etc.

The Anticorruption Programme creates the organization's ethics strategies and sets down required behaviour rules. It illustrates how it is possible to implement ethical values as core competencies into human resource practices. The acute need exists in changing the HR professionals' role, i.e. to participating in development and enforcement of ethics policies and HR practices oriented to ethical values, and assessing perceptions about municipality's leadership. This means that:

HR services, i.e. recruitment, selection and redeployment, should integrate competencies and ethics values as assessment criteria,

Employee training and development put into practice ethics and corruption programmes as learning topics among other ones,

Effectiveness of training related to the Code of Ethics as well as a reduction of corruption factors should be assessed so that the re-design, enforcement, communication and modification of ethical strategies and HR practices supports ethical behaviour of officials,

- The provision of consistent and credible information about the Municipality is a precondition for building employee trust and organizational loyalty, e.g. surveying employee opinions how public officials view leader's behaviour and what ethical issues are most critical. 


\section{Conclusions}

The Czech political, economic and social systems provide a stabilized environment for the development of a civic society. Current conditions characterised by a steadily growing living standard and a high social peace shift the focus of both private and public organizations to ethical reasoning. In the public sector we encounter an intense need to change the social status and partly the employment security of public officials as a precondition for the reestablishment of traditional public administration values and ethics. Architects of public management reforms should take into account that new public management practices have influence on ethical behaviour and public officials' attitudes. The prevailing emphasis on productivity and effectiveness focuses on outcomes instead of processes, like e.g. developing, implementing and controlling an equal opportunity policy, taking care of relationships between citizens and public officials, disseminating information about a friendly access to public services etc. HR policies and practices applied by territorial self-government authorities rather lag behind the social need to learn and practise ethical reasoning. The political elite together with public management should constantly take responsibility for supporting such HR policies and practices that integrate ethics values as assessment criteria into core competencies of public officials, especially into recruitment, selection, promotion, training and development. Some central state institutions and large municipalities become good examples for other public organizations because among other things they elaborate and publish codes of ethics, use ethical criteria in rigorous employee selection, and train public officials in topics dealing with corruption acts and anticorruption measures. However, the process of leadership development based upon ethics is rather long-term. The society suffers from the lack of public leaders positively motivating others. Territorial self-governments, like municipalities and mainly smaller towns, should benefit from servicing the local community. They face chances for the development of openness, integrity and fairness as local public management and officials personally collaborate with citizens and frequently obtain informal feed-back about their behaviour.

\section{Note}

1. Stanislav Gross was the minister of interior, the first deputy chairman of the Government and the deputy chairman of the Czech Social Democrats Party from April 2000 till June 2004. After the European
Parliament election that Social Democrats lost and the consequential governmental crisis he replaced Vladimir Spidla in the party leadership (June 2004) and in the Prime Minister position (August 2004). At the end of January 2005 the daily newspaper Mlada fronta Dnes criticised doubtful financial sources spent on purchasing of his Prague flat (4.2 mil. Czech crowns). The media as well as the Czech office of the Transparency International broadly criticised him for his explanations about an alleged loan provided by a poor relative. The opposition party - the Civic Democrats Party - also lobbied against him in the Parliament. Further, he was criticised that as the minister of interior he established several police teams subordinated directly to him without any clear purposes. At the same time the weekly newspaper Respekt called attention to that Mrs. Sarka Gross' enterprise bought a house for 5.9 mil. Czech crowns and explained it with an unspecified credit. Hereafter, the Respekt pointed out the connection between Mrs. Gross and a lady owning and running a fancy house. Gross announced several times under the pressure of the public and the opposition that „he abdicates”, but in no time he cancelled his statements. From the mid till the end of April negotiations were treated beyond political parties and resulted into an agreement on a Government coalition under Social Democrats leadership till 2006 elections. This finally led to Gross' resignation (25.4.2005) after a four-month governmental crisis.

\section{References}

Act No. 312/2002 Col., on Territorial Self-government (in Czech).

Branine, M. and Dvořáková, Z. (2000) International Human Resource Management: Factors of Convergence and Divergence. Politicki ekonomie, 48(1), p. 83-96 (in Czech).

Corruption Report in the Czech Republic in 2004 and Performance Report about Updated Governmental Anticorruption Programme. (2005) Praha: http:// www.mvcr.cz/reforma/zpravy/zpravy.html, 43 p. (in Czech).

Dvořáková, Z. et al. (2004) Glossary of Human Resource Management. Praha: C. H. Beck, 157 p. (in Czech).

Ethical Reasoning Mini-Guide. (2005) Academic Development Centre, Mount Royal College, Calgary, A B.http://www.mtroyal.ab.ca/cr/ outcomes.php?mode $=3$.

Frederickson, H. G. and Walling, J. D. (1999) Editors' Introduction. Ethics in Contemporary Human Resources Management. Public Personnel Management, 28(4), p. 501-504. 
Guest, D. E. Human Resource Management and Industrial Relations. Journal of Management Studies, 1987, 24(5), p. 503-521.

Kleibl, J.; Dvořáková, Z. and Šubrt, B. (2001) Human Resource Management. Praha : C.H. Beck, 264 p. (in Czech).

Koudelka, F.; Bakešová, M. and Štainer, M. (2005) Requirements of HR Development in Regional, Municipal and Local Authorities of Public Administration. Final Report of Sociological Research. Olomouc: Edukol, 65 p. (in Czech).

Maříková, H.; Petrusek, M.; Vodákova, A. et all. (1996) Extensive Glossary of Sociology. Praha: Karolinum, 1627 p. (in Czech).

Pomahač, R. and Vodákova, O. (2002) Public Administration. Praha: C.H. Beck, 278 p. (in Czech).

Šimčíková, S. (2005) Personnel Management in Public Administration. Manuscript. Praha: University of Economics, 15 p. (in Czech).
Sparrow, P.R. and Hiltrop, J.-M. (1994) European Human Resource Management in Transition. New York/ London: Prentice Hall, 702 p.

Vermeulen, P. (1998) The Civil Servant, Society and the Citizen in Quest of Good Ethical Behaviour. p. 171188.

Vigoda, E. (2000) Are you being served? The Responsiveness of Public Administration to Citizens' Demands: An Empirical Examination in Israel. Public Administration, 78(1), p. 165-191.

\section{Internet sources}

http://cs.wikipedia.org/wiki/Stanislav_Gross http://portal.gov.cz/wps/portal/_s.155/6966/place http://www.korupce.cz http://www.praha-mesto.cz http://www.reforma.vlada.cz http://www.statnisprava.cz 